\title{
Catalytic aminolysis from esters and carboxylic acids in ionic liquids: mechanism, enhanced ionic liquid effect and its origin
}

\author{
Vanda Maria de Oliveira, ${ }^{a, b *}$ Richard Silva de Jesus, ${ }^{b}$ Paulo A. Z. Suares, ${ }^{a}$ Joel C. \\ Rubim, ${ }^{a}$ and Brenno A. D. Neto, ${ }^{c}$
}

a Laboratório de Materiais e Combustíveis, IQ-UnB, Brasília, DF, Brazil. ' Laboratório de Síntese Orgânica e Inorgânica, Universidade Católica de Brasília (UCB). ' Laboratory of Medicinal and Technological Chemistry, University of Brasília, Chemistry Institute (IQ-UnB).

*wanddynha@gmail.com

Keywords: catalytic aminolysis, ionic liquid, esters and carboxylic acids.

\section{INTRODUCTION}

Catalytic methods that perform new bond formation and/or cleavage are of great interest. Nowadays, the development of new catalytic systems to promote important transformations in environmentally acceptable reaction media is imperative due to ecological, safety and security reasons. ${ }^{1}$ In this sense, ionic liquids are regarded as a green media due to their unique set of physical-chemical properties such as negligible vapor pressure, good chemical and thermal stabilities, relative low flammability, relative low viscosity and others. Based on our large experience using ionic liquids in catalytic processes, ${ }^{2}$ we disclose herein a new methodology to promote the aminolysis reaction (amide formation) from esters and carboxylic acids in ionic liquids (Escheme 1).

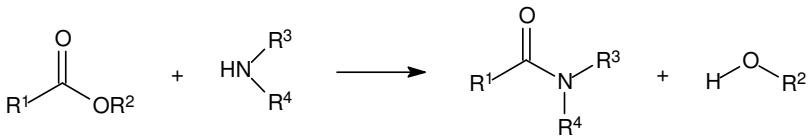

Scheme 1. General example of aminolysis reaction.

\section{RESULTS AND DISCUSSION}

Major results of the testes conditions are summarized in Table 1.

Table 1. Reaction of methyl oleate $(1.00 \mathrm{mmol})$ and pyrrolidine $(2.00 \mathrm{mmol})$ in different solvents at $135{ }^{\circ} \mathrm{C}$ for $18 \mathrm{~h}$ (catalyst $=0.05 \mathrm{mmol}$ ) .

\begin{tabular}{cccc}
\hline Entry & Catalyst & Solvent/lonic liquid & Yield (\%) \\
\hline 1 & $\mathrm{BF}_{3} \cdot \mathrm{OEt}_{2}$ & Toluene & 17 \\
2 & - & BMI.NTf $_{2}$ & 56 \\
3 & $\mathrm{BF}_{3} \cdot \mathrm{OEt}_{2}$ & BMI.NTf $_{2}$ & 99 \\
4 & $\mathrm{BF}_{3} \cdot \mathrm{OEt}_{2}$ & BMI.BF $_{4}$ & 94 \\
5 & $\mathrm{BF}_{3} \cdot \mathrm{OEt}_{2}$ & BMI.PF $_{6}$ & 98 \\
6 & $\mathrm{CdO}$ & BMI.NTf $_{2}$ & 98 \\
7 & InCl $_{3}$ & BMI.NTf $_{2}$ & 75 \\
8 & $\mathrm{Ce}\left(\mathrm{NO}_{3}\right)_{3}$ & BMI.NTf $_{2}$ & 97 \\
9 & $\mathrm{SnCl}_{2}$ & BMI.NTf $_{2}$ & 99 \\
10 & $\mathrm{H}_{2} \mathrm{SO}_{4}$ & BMI.NTf $_{2}$ & 99 \\
\hline
\end{tabular}

As shown in Table 1, the ionic liquid effect plays an important role in the aminolysis reaction. ESI-QTOF-
MS(MS) helped to a better comprehension of the transformation, indicating the possibility of two or more metal center to promote the reaction (Figure 1).

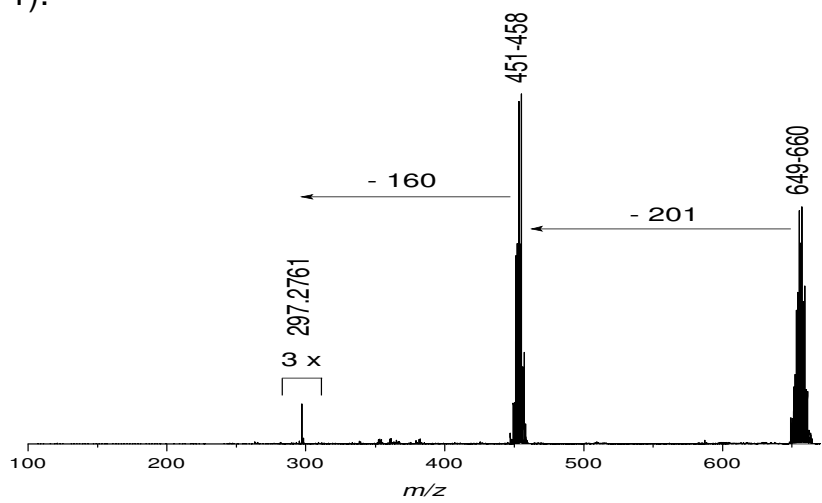

Figure 1. $\mathrm{ESI}(+)$-QTOF product ion spectrum of $\mathrm{CdO}$, pyrrolidine and methyl oleate mixture in an acid methanolic solution $(0.01 \%$ formic acid).

The presence of methyl oleate and pyrrolidine associated to the metal center is clear from the spectrum. The ion of $m / z 649-660$ is attributed to a complex composed of two $\mathrm{Cd}$ atoms, one methyl oleate, one pyrrolidine and one formiate. The loss of $201 \mathrm{Da}$ is attributed to $\mathrm{Cd}(\mathrm{OH}) \mathrm{C}_{4} \mathrm{H}_{9}$, that is one pyrrolidine molecule directly bonded to $\mathrm{CdO}$.

\section{CONCLUSION}

In summary, we have demonstrated the efficiency of the catalytic system using $\mathrm{CdO}$, or $\mathrm{SnCl}_{2}$ or $\mathrm{BF}_{3} \cdot \mathrm{OEt}_{2}$ as catalytic Lewis acids supported in imidazolium-based ILs as great promoters of the aminolysis (amide formation) reaction from esters or carboxylic acids.

\section{ACKNOWLEDGEMENTS}

CNPq, FAPDF, CAPES

\section{REFERENCES}

${ }^{1}$ (a) Tilman, D.; Hill, J.; Lehman, C. Science 2006, 314, 1598-1600.

${ }^{2}$ (a) Pinto, A. C.; Lapis, A. A. M.; da Silva, B. V.; Bastos, R. S.; Dupont, J.; Neto, B. A. D. Tetrahedron Lett. 2008, 49, 5639-5641. (b) Prechtl, M. H. G.; Scholten, J. D.; Neto, B. A. D.; Dupont, J. Curr. Org. Chem. 2009, 13, 1259-1277. 